\title{
Post-Truth Döneminde Epikuros'ta Mutluluk ve Dostluk Kavramlarını Yeniden Düşünmek
}

\section{Yavuz YILDIRIM ${ }^{1}$}

\section{Rethinking Happiness and Friendship Concepts of Epicurus at Post-Truth Era}

\section{ARTICLE INFO}

Article History:

Date Submitted: 14.04.2017

Date Accepted: 07.09.2017

\section{JEL Classification:}

B10

B11

B31

Keywords:

Politics in Epicurus

Ancient Thought

Hellenism

Epicurean Thought

\begin{abstract}
Epicurus would like to investigate the man and his Nature against the thought of conventional Ancient World. It was an era of a transition which the cultures and places has converged each other and collapsing the Ancient thought. The searching of new world in Epicurean thought is based on the concepts like to be free from the pain and to reach the pleasure and friendship as an end. The aim was to protect and rethink the physical and mental situation of person in the disturbing process of new political era. In order to this aim he had imagined to make a new community based on friendship to reach the tranquility. The politics which he refused is the traditional way of Ancient thought and also established way of his era. In this context Epicurus give some clues to find an exit of today's unstable and disturbing post-truth discussions in rethinking the individual, pleasure and friendship.
\end{abstract}

\footnotetext{
${ }^{1}$ Yrd. Doç. Dr., Niğde Ömer Halisdemir Üniversitesi, İktisadi ve İdari Bilimler Fakültesi, Siyaset Bilimi ve Uluslararası İlişkiler Bölümü Öğretim Üyesi, yavuz.yildirim@ohu.edu.tr
} 


\section{Özet}

Yeni kültürlerin ve yerlerin birbiriyle temas kurmasıyla evrensel olana dair eski tespitlerin değiştiği bir geçiş döneminde Epiküros bireyi yeniden keşfetmek istemiştir. Acıdan uzak durma ve bir amaç olarak haz ve dostluk kavramlarıyla Epiküros'un kurmaya çalıştığı yeni dünya, döneminin dalgalanmalarından ve kargaşasından bireyi uzak tutma ve kendini bulma arayışıydı. Epiküros'un farkı bu pratiklerin merkezine bireyin duyumlarını alması, ancak bu duyumların tek başına bir kurtuluşu değil mutluluk verici bir topluluk ilişkisi içinde temkinli ve dingin bir düzeni kurmak fikrini desteklemesidir. Reddettiği siyaset ise geleneksel ve o dönem için yerleşik olan türden olan siyasettir. Bu açıdan Epiküros, bugün hakikatin ne olduğunun yeniden tartışıldığı ve manipülatif yönlendirmelere açık olduğu bir geçiş döneminde yeni çıkış/kaçış arayışları için imkanlar sunmaktadır.

Anahtar Kelimeler: Epiküros’ta Siyaset, Antik Düşünce, Hellenizm, Epikürcülük.

\section{Giriş}

1990'ların sonunda sosyalizmden demokrasiye geçiş döneminde Batı dünyasındaki umut, küreselleşmenin beklenen zenginliği yayamaması, tersine yeni bir eşitsizlik üretmesiyle karamsarlığa bırakırken 2000'ler, krizlerin süreklileştiği, çılgınca fikirlerin aniden parladığı ve desteklendiği büyük dalgalanmalara sahne oluyor. Oxford sözlüğü, tam da bu kargaşayı özetleyen post-truth'u (hakikat-sonrası) 2016 yılının kelimesi seçmişti (https://en.oxforddictionaries.com, 2016). Bu kavram bilgiden ziyade inancin yönlendirici olduğu, bu inancın anlık spekülasyonlarla yönlendirildiği, neyin doğru neyin yanlış olduğunun karıştı̆̆ 1 bir dönemi simgelemekteydi. Bu kargaşa ortamında, eskiden beri kötülenen siyaset de yalanlarla iç içe geçmiş bir hal alırken kitleler, geçerliliği doğrulanmak zorunda olmayan kavramlara geçici süre de olsa boğulmak zorunda kalmaktadır (Davies, 2016; Dunt, 2016).

Gerçeğin, hakikatin ne olduğunu tespit edememek yeni bir içe kapanma sürecini beraberinde getirir. İngiltere'nin AB'den çıkma girişimi, ağzına geleni söylemekten çekinmeyen, yabancılara ve kadınlara yönelik dışlayıcı tavırlarıyla bir siyasi çizgiden çok bir TV yıldızını andıran emlak milyarderi Trump’ın ABD Başkanı seçilmesi, terörün ve 
güvensizliğin dünyanın her yerini ele geçirmesi bu katastrofik durumun belli başlı gelişmelerini oluşturur. Bu süreçte siyasetten uzaklaşmak bireyse anlamda tercih edilen yol haline gelirken, siyasetin kendisi de siyasal tartışmaları bitiren ve onun erine ne olduğu belli olmayan siyaset-sonrası düzeni yerleştirmeye başladı. Kişisel mutluluğun önemsendiği, toplumdan kaçışın arttığı, tedirginliğin ve risklerin arttığı bu dönemde siyasetin hangi eksenlerde yeniden üretilebileceğini düşünmek önem kazanmaktadır. Bireylerin kendilerini güvende hissetmediği, sürekli aldatılma ihtimallerinin olduğu, bunu en açık şekilde televizyonlarda, medya ortamlarındaki bilgi bombardımanı altında yaşadıkları bir dönemde bireyin dayanak noktası alacağı unsurların, yakın olduğu grupların, toplulukların ve bunlarla birlikte kuracakları yeni bir siyasetin önemi giderek artmaktadır. En başta ve en temelden kişisel olanın, özel alanın nasıl şekillendiği, mutluluğun ve hazzın ne olduğu, bireysel kaçışın nasıl bir ortam yaratacağı bugün yeniden sorgulanmalıdır. Epiküros kendi döneminde bu sorgulamayı yapmıştır.

Benzer bir geçiş ve kargaşa dönemi, Antik Dünya'nın Helenizm’e dönüştüğü süreçte de görülmüştü. Yeni kültürlerin ve yerlerin birbiriyle temas kurmasıyla evrensel olana dair eski tespitlerin değiştiği bir geçiş döneminde Epiküros bireyi yeniden keşfetme eğilimindeydi. Acıdan uzak durma, haz ve dostluk kavramlarıyla Epüküros'un kurmaya çalıştığı yeni dünya, döneminin dalgalanmalarından ve kargaşasından bireyi uzak tutma ve kendini bulma arayışıydı. Bunu kendinden önceki dönemin yurttaş ve kentin kollektivitesine dayalı düşüncesinden farklılıklarla temas eden ve yeni sınırlarla tanışan bireyin mutluluk arayışına "gerçi çekilerek" yaptı. Çabası belki de köklere dönüp yeniden yola çıkmak olarak el alınabilir, çünkü yeni bir dünya, kozmopolis, doğuyordu ve yeni sorunlarla başa etmenin yoluna aramak gerekmekteydi. Bu kez acı veren deneyimlerden kurtulup yeniyi, mutluluğa dayalı bir topluluğa dayandırmak istedi. Böylece ulaşacağı evrensel, yeni bir topluluk, ortak acıda buluşan yurttaşlar değil ortak mutlulukta buluşan dostlar topluluğunun eseri olacaktı.

Helenistik düşünce, evrensel arayışı içinde sonraki çağlara pek çok miras bıraktı. Öncelikle dinsel cemaatin boyun eğdirici çileciliğinde buluşturduğu kitle, aklın 1şığında bireyin aydınlanmasıyla eleştirildi. Batı’nın düşünce dünyası akıl aracılığıyla dünyevi “büyük anlatı" ideolojilerin belirleyiciliğinden ve kitlesel uğraşılarından demokrasinin temsilciliğine doğru yol alırken 20. yüzyılın sonunda küreselleşme ve piyasacı bakışın zenginleştirici 
hedefleriyle sınırları kaldırıp yeni evrenseller kurdu. Küreselleşme-karşıtlarının yükselttiği başka bir dünya mümkün arayışı, tıpk1 1968'te olduğu gibi bireyi yeniden düşünmeye sevk etti. 1968 'te kitle toplumunun yabancılaştırmasından kaçmak isteyen birey, küreselleşme döneminde de bu kez piyasanın görünmez elinin yarattığı soyut dengelerden muzdarip durumda yeni bir çıkış yolu aramaktadır. Bu kez demokrasi de yardımcı değil çünkü kurumsallaşmış demokraside halkın görünürlüğü de iyice minimize olmuş durumdadır.

$\mathrm{Bu}$ noktada bireyin yeniden hatırlanması, mutluluğun ne olduğunun tespiti, aranan yeni dostların nasıl bir kollektivite kuracağı ve nasıl bir evrensele doğru yol alacağı önem kazanmaktadır. Bu açıdan Epiküros’un düşüncelerini bugünün kıskaçları altında yeni çıkış yolu olarak hatırlamak ve düşünmek gereklidir. Bu çerçevede yeni bir içe kapanmacılık öneren aşırı-sağın acı verici yoluna sapmamak adına mutluluğun sadece bireysel değil kendi gibilerle birlikte bir dostluk ortamı olduğunu hatırlatan Epiküros'un 21. yüzyılın başında yeniden ele alınması önemlidir. Çalışmada Epiküros'un düşünceleri aktarılırken, ilham verdiği düşünürler de yer yer anılacak ve buradan yeni açılımlara imkan verecek noktaları öne çıkarılacaktır.

\section{Helenistik Geçiş Dönemi²}

Helenistik düşünce, Antik Yunan'ın -özellikle Atina'nın- içe kapalı ve kendinden menkul yönetim tarzının/düşünme kültürünün gevşediği ve kent-devletlerin iç ve dış sorunları sonucunda diğer kent-devletleri ile daha yoğun iletişime geçtiği bir dönemde doğmuştur. Özellikle M.Ö. 339'da Makedon Kralı II.Philippos önderliğindeki orduların Yunan ordularını yenmesiyle birlikte, kent-devletlerin bağımsızlıkları yok olmuş ve egemen devlet durumlarını yitirmişlerdir. Bunun sonucunda, bir yandan kent-devletlerin sayısı artarken, diğer taraftan da kültürel etkileşim artmıştır. Söz konusu kültürel etkileşim ile Yunanlılar, doğuluların "barbar" ve kendilerinden farklı olduğu düşüncesinden kopmaya başlamıştı. Polisin kendine dair sorunları çözememesi ve dışarıdan bir müdahale sonucu bağımsızlığını yitirmesi, o döneme kadar üretilen felsefi yaklaşımların eleştirilmesine ve yeni yaklaşımların gelişmesine de ön ayak olmuştur. Özellikle Platon ve Aristoteles'in polisi eleştirmelerine rağmen çözümü onun

\footnotetext{
${ }^{2}$ Bu başlıkta atıf yapılan isimler dışındaki kısımlar Gökberk (1996), Sabine (1966) ve Russell'ın (1969) ilgili bölümlerinden özetlenmiştir.
} 
içinde arayan ve dışa kapalı düşünüş sistemleri, köklü şekilde eleştirilmeye başlamıştı. Polisin kendine yeterliliğini yitirmesi, felsefi düşüncede polis merkezli yaklaşımların terk edilmesine neden olmuştur. Arsitoteles'te son halini bulan denge arayışı ve yanlış yönetimlerin bir tür karışımı olarak doğru bir merkez bulmak ihtiyacı, her iki yöne birden -bireyselcilik ve evrenselcilik yönünden- bölünmeye uğramıştır.

Siyasi rejim onlar üzerinden kurulsa da, gerek Platon'da gerekse Aristoteles'te kontrollü bir şekilde siyasi merkezi dışında tutulmak istenen halk, polisin çözülüşü ile birlikte, daha fazla görünür hale gelmekteydi. Kendinden menkul bir polis idealinde bir arada tutulan bu insanlar, idealin çözülmeye başladığını gördükçe, ona bağlılığın çözüm getirmediği ve siyasette şeklen de olsa yer almanın bir anlam ifade etmediği ruh haline doğru sürüklenmekteydi. Aristoteles bu sıkıntının arttığı dönemlerde, siyaset yapma işini çalışmayan ama erdem sahibi sınıflara bırakarak, merkezi bir tür boşaltma ve siyaset üzerinden siyasetsizleştirme çabasına girerken, çalışan sınıflara da mal-mülk edinerek servet edinme hakkını vermekteydi. Siyaset yapmak yerine çalışmak ve böylece siyasi merkezden uzak kalmak zorunda olan kesimler, polisin bağımsızlı̆̆ını yitirmesiyle birlikte artık kaderci ve bireyci bir tutum takınmak için yeterli ortama sahip olmuşlardı. Böylece kendi kendine yeterlilik, bireysel mutluluk, kendine dayanarak iyi bir hayat kurmanın siyasi ve sosyal yapısı hazır hale gelmişti. Diğer bir deyişle dinginlik ve kişisel mutluk ülküsü, toplumsal yaşamdaki kargaşanın yarattı̆̆ı değer boşluğuna yanıt olarak kendini gösterir. Bu zeminde salt bireyin mutluluğu ile onu kozmopolit bir dünya devleti yurttaşlığına bağlayan iki önemli akım, Epikürosçuluk ile Stoacılık, Helenizmin tipik iki düşünüş tarzını yansıtır; bu akımlar Roma'da yeniden canlandırılarak modern düşüncenin de temellerini oluşturacaktır.

Helenistik dönem, Roma etkisinin kurumsallaşarak arttı̆̆ı döneme kadar devam eden bir geçiş sürecidir. Siyaset felsefesi açısından Büyük İskender'in 323'teki ölümünden Cicero'nun 43'teki ölümüne kadar düşünülebilir (Nelson, 2015: 70). Helenistik sözcügü̈, İskender'in yarattığı kültürel dünyaya dairdi. Diğger bir deyişle idealleriyle birlikte düşünülen polis’ten pratik gerçekliğin kozmopolis'ine doğru bir dönüşüm yaşanmıştır (McClelland, 1996: 75). 
Siyasal düşüncenin merkezine yurttaş-insan'dan çok birey-insan'ın alınmaya başlandığı bu dönem, bir geçiş dönemidir. Yeni kurulan düzende, kentlerin önem orduya ve askeri düzene geçmişti; birbirine benzeyen inşaların yaşadığı küçük kentler yerin farklılıkların ve çeşitliliğin aldığı kutsal bir devlete doğru evriliyordu. Bir yandan eski alışkanlıkları korumak bir yandan da yeni dünyaya adapte olmak, özel ile genel arasındaki farklılığ1 belirginleştirmişti. Grekler kimi alışkanlıklarını ve ayrıcalıklarını kaybederken, daha öncenin ezilenleri ve mağdurları görünür hale gelmişti (Sharma ve Sharma, 2006: 191-192). Bu geçişte insan, toplumsal özü kendisine ait olarak görmek ve ortak yaşamın zorunlu kıldığ etkinliklerden kendisini geri tutmak yoluyla, bir benlik kazanmanın olanağını bulmaya çabalayacaktır. Böylece, polisin düşünsel temelinin dayandığı ancak tek başına bir anlam ifade etmeyen birey, kendinden bir varlık olarak polisi hatta onunla sınırlı kalmadan, evrensel olanı anlamlandırmaya başlayacaktır. Bu çaba sonucunda insan, kişiliğini toplumsalın dışında arayacak ve onu öznel istencinin keyfi yüklemlerinde bulacak ve benimseyecektir. İnsanların polisten bağımsızlaşarak kendilerine bir ruh edindikleri bu süreç, birkaç yüzyıl içinde dinlerin güçlenişi ile taçlanacaktı. Bu süreçte evrensel hale birey, kendi istenciyle toplumun gerekleri arasında var olan birlik ve etkileşimi yok sayarak toplumsal özün yerini bölünmüşlügün almasını sağlayacaktır. Söz konusu bölünmüşlük din dolgusu ise doldurulsa da her daim canlılığını koruyarak modern düşünüşün temelini atacaktır.

Helenistik dönemde yaşanan dönüşümle, iki türlü düşünüş tarzının ortaya çıktığı belirtilmektedir: Bir yanda insanın kendi hayatını düzenlemesi öte yanda diğer insanlarla ilişkilerin düzenlenmesine dair görüşler. Bunlardan birincisine bağlı olarak davranış felsefeleri üretilirken, ikincisi için de insanlararası kardeşlik fikirleri geliştirilmişti. Söz konusu ayrılma ile birlikte, insanlararası tür benzerliğine, bir de us benzerliği (homonia ya da concordia fikri), onu ortak bir aile ya da kardeşlik haline getiren bir gönül birliği düşüncesi ekleniyordu. Böylece yaratılan uyum, bir yandan dönemin karışıklık içindeki sosyo-politik düzeninden kopmayı, bir yandan da önceki -Antik Yunan düşüncesi- dönemde olmayan bir bakış açısını, farklı düşüncedeki insanların nasıl bir arada yaşayacağına dair önermeler sunuyordu. Ödeve uygun davranmak düşüncesi "kendine yeterlilik" (bireycilik) ile "doğanın kanunlarına uygunluk" (evrenselcilik) olarak dengeli bir toplum için öne çıkmaktaydı. Helenistik dönemde, kapsayıcı hukuk, insan hakları-evrensel bağlayıcı adalet-insanlık egemenliği gibi kavramların temellerinin atıldı̆̆ı söylenebilir. 
$\mathrm{Bu}$ çerçevede siyasetin, toplumun ve bireyin ele alınışında yeni düşünsel temeller özellikle Roma ile birlikte somutluk kazanacak, din başta olmak üzere kurumsallaşan siyasi pratikler sonraki dönemde belirleyici olacaktır. Epiküros'un farkı, bu pratiklerin merkezine bireyin duyumlarını alması, ancak bu duyumların tek başına bir kurtuluşu değil mutluluk verici bir topluluk ilişkisi içinde temkinli ve dingin bir düzeni kurmak fikrini desteklemesidir.

\section{Birey, Topluluk ve Haz}

Epiküros (M.Ö. 341-270), "Bahçe" adını verdiği okulda kendi adıyla özdeşleşen düşünceler bütününü oluşturmuştur. Kentin dışındaki bir Bahçe'de yürüttüğü eğitimi, kentle ilişkili ama içinde olmayan bir ekole dönüşmüştür; Epiküros, yeni bir dünya ve yeni bir insan kurmak istemiştir; kendi dünyasını, kapalı topluluğunda somutlaştırmıştır. Epiküros çok fazla yazılı eser bırakmamıştır; düşünceleri daha çok mektupları ve çeşitli konulardaki çalışmalarının toparlandığı eserleri bulunmaktadır (Wilson, 2015:6). Epikürcülük özellikle Roma döneminde düşüncelerinin Latince'ye çevrilmesiyle yeniden canlanmıştır. Burada Lucretius'un şiirlerinin önemli bir arac1 olduğu söylenebilir (Hammer, 2014: 107). Bu dönemde Epikürcülüğün, otoriteyi elinde bulunduran patricilerin tepkisini topladığı görülür (Wilson, 2015:85). Bu açıdan Epiküros'un düşünceleri, modern dönemde çoğunlukla Roma Epikürcülüğü üzerinden ele alınmaktadır; bu da Roma'daki tartışmaların içinde yeniden yorumlanmasına ve çoğunlukla kötülenerek yanlış yorumlanmasına neden olmuştur. Özellikle Cicero'nun Epiküros'u ele alış1, sonraki kuşaklara bu düşüncelerin biraz da değiştirilerek aktarılmasında etkili olmuştur.

Esasen düşünceleri Antik dönemlerde hem Grekler hem de Grek olamayanlar arasında yaygınlık kazanmıştır, bu nedenle çabasını bir yere ya da yöreye özgü görmek mümkün değildir. Platon idealizmine ve Pyrrho'nun şüpheciliğine tepki olarak düşüncelerini geliştirmiştir. Birbirini etkileme açısından Şüpheciler, Epikürcüler ve Stoacılar sıralaması daha doğrudur. İyonya geleneğinden olumlu, Platoncu gelenekten olumsuz etkilenmiştir. Modern dönemde Spencer ve Comte gibi düşünürlerde görülen sentezci bir yapıya sahiptir. Sadece teorik fikirleri üreten bir filozof olarak değil döneminin normlarını sorgulayan ahlaki reformcu olarak ele alınmalıdır. Ancak De Witt'in belirttiği gibi Epiküros'un adı, siyasetten sosyal erdemlere doğru hat kuran düşünceleri onaylandığında anılmazken kötülendiğinde 
anılır (De Witt, 1954:8). Özellikle Roma döneminde Stoacılık ile iç içe geçen görüşleri Epiküros'un farklılıklarını gölgede bıraksa da Stoa düşüncesinden farkı, bireyin eylemlerine yüklenen farktan kaynaklıdır (Brun, 2006: 78-80). Esasen Epiküros bireyi anlamaya, Stoa ise onun boyun eğeceği bir düzen kurma fikrine odaklanmaktaydı. Epiküros, dönüşümün doğurduğu karmaşada bireyin gidişata ayak uydurmak yerine daha sakin sulara çekilerek nasıl mutlu olabileceğini soruşturmuştur. Onun otoriteye karşı çıkılan ve bireysel kaçışlarla yeni çıkışlar aranan dönemlerde, örneğin Hrıstiyanlık'ın kuruluş süreçlerinde ya da aydınlanma döneminin birey ve akıl arayışında, sermaye birikiminin artıp gelir uçurumunun arttığı dönemlerde yeniden hatırlanmasının nedeni bu arayıştır.

Epiküros felsefesinin sac ayakları, mantık, fizik ve ahlaktır. Mantık ve fizik, ahlak için bir giriş niteliğindedir. Dolayısıyla temel olan ahlaka ilişkin görüşleridir. Ahlaksal yaşam genel anlamıyla, korkulardan kurtulup, mutluluğa ulaşma yolundaki engellerin kalkmış olması, hazza yönelmek anlamlarına gelir. Erdem ise mutluluğu aramada bir öngörü oluşturur. Erdem, doğruyu yaşamak için araçtır. Ahlaksızlık ise tedbirsizliktir; acıya yönelten şeydir. Kendini denetimsiz bir imgeleme bırakan kişi, asıl tehlikelerin nerede olduğunu görmez. Dolayısıyla Epüküros'ta mutluluk toplumsal normlardan koparılsa da, kendi içinde bir bütünlükten ve ona ulaşmaya dair normlardan koparılmamıştır; mutluluğa ulaşmak bireysel olsa da belli bir yola-yaşam şekline aittir. Bu yolun hedefi mutluluk, en büyük yardımcısı dostluktur. Kişisel ve diğerleriyle birlikte bir dinginlik, engin denize birbirine çarpmadan yol almak gibi bir huzur verecektir. Epiküros'a göre insan ruhu iki ana kategoriden oluşur; bunlardan birincisi ise üç alt kategoriye ayrılır. Buna göre ateş, soluk ve hava, ruhun bedenin bütününe yayılmış ve aklın bulunmadığı yerlerini oluşturur; logikon ise göğüste bulunur ve ruhi, tinsel hayatın taşıyıcısıdır. Bu parçalar, ölümle birlikte dağılır; böylece daha sonra da değinilecek olan, ölüm korkusunun anlamsızlığı ortaya çıkar; çünkü insan öldüğünde artık bir bütün ve dolayısıyla kendisi değildir. Dolayısıyla, insanı ve mutluluğu anlamak için, onun yaşamsal özelliklerine ve deneyimlerine bakmak gerekir (Ağaoğulları, 2006: 404-405).

Epiküros gerçeğe bütün ve parça ilişkisi bakımından yaklaşmıştır, bu açıdan tümdengelimcidir. Birey, doğanın parçasıdır. Akıl'ı değil Doğa'yı gerçeğin normu olarak önemsemiştir ancak De Witt'e göre (1954:5) emprisit olarak adlandırılması yanlıştır, bilginin tek kaynağı olarak duyguları göstermemiştir; Doğa'dan gelen duyumların merkeze alınması 
tüm duyguların güvenilir olduğunu anlamına gelmez. Birey, duyularıyla birlikte vardır ve duyuların kontrolü bireydedir. Doğru ve yanlış fikirler arasında yatığg ayrımla biri itici/nahoş diğeri etkileyici iki dünyanın sınırlarını kurmuştur. Daha sonra görüleceği gibi siyasal kariyeri özendirmemesi hırsları kötülemek, kutsal tanrısallığı reddetmesi ortodoksiyi ve hazcılığı çekingen saygınlığı kötülemek içindir (De Witt, 1954:6-8). Reddettiği dünyanın kötü fikirlerinin karşısına yeni fikirler koyarken, merkeze bireyin yeniden düşünülmesini almıştır.

Epiküros düşüncesinin temelinde mutluluk (eudaimonia) kavramı yatar. Epiküros için felsefe, mutluluğa ulaşmayı sağlayacak araçları araştırmaktır. Ancak onun kavramlaştırmasında mutluluk, Antik Yunan düşünürlerinden farklı bir içerik alacaktır. Mutluluk, bireysel ahlak ile temellendirilir. Buna göre mutluluk nihai amaçtır. Mutluluk, kişisel hazlar, kişiyi sakinliğe ve huzura ulaştırarak kendisi haline getirecektir. Dolayısıyla aşağıda yenden değinileceği gibi, mutluluk arayışı ya da hazcılık, Epiküros’ta çoğunlukla bencillikle/egoizmle eşleştirilse de buradaki egoizmin olgunluğa götüren bir yol olduğu görülebilir. Siyaseti kötülemesi, kitlelerin ve monarkların geçici isteklerine kötülemek içindir. Devlet ya da teoloji merkezli değil insan merkezli bir düşünce geliştirmiştir. Bu onun yanlış biçimde egoist hazcı olarak adlandırılmasına yol açtı ancak o "alturist (fedakar) hazcı" olarak nitelendirilebilir (De Witt, 1954:30). O'Keefe'ye göre de (2010) Epiküros hazc1lı̆̆ aydınlanmış bir hazcılıktır; çünkü erdemli bir insan olma yolunda işler. Bu duruma daha sonra, özellikle eğitim meselesinde yeniden değinilecektir.

Ancak, tıpkı Sokrates’te olduğu gibi Epiküros için de bilgi olmadan, mutluluk olmaz. Bilgi için olayları önce algılamak, sonra algıları dikkatle ve de düzenli bir biçimde birleştirmek gerekir. Fizik bilgisi bunun için gereklidir. Fizik, boş inançlardan ve ölüm korkusundan kurtulmak için araç olacaktır. Huzur ve barış içinde yaşamak için doğayı gizeminden ayıklamak gerekir. Doğayı tanımadan saf hazlara ulaşılamaz. Epiküros Doğa'yı bir öğretmen olarak görür. $\mathrm{Bu}$ anlamda Epiküros, materyalisttir. Mantık ise doğruluğun ölçütlerini anlamaya yarar. Bu ölçütler, algılar, kavramlar ve duygulardır. Buna göre daha önceden kazanılmış algıların yinelenmesinden oluşan tasarımlar, kavramları oluşturur. Algılar ve kavramlar, duygularımızın niteliğini belirler; duygular haz veya acılardan oluşur. Doğru veya yanlış dolayısıyla haz veya acı, bilgiye bağlıdır; bilgiye ulaşmak, kavramları doğru algılayıp insanı mutluluğa ulaştıracaktır. 


\section{Bilgi ve Maddecilik}

Epiküros'un fizik anlayışı, atomlar ve boşluk kuramına dayanır. Demokritos’tan alınma atom kuramı, insan bilincinin bir göstergesidir. Bir tür boş mekan içinde seyreden atomlar, nedensiz olarak düşerler, ama düşüşleri belli bir zorunluluğa bağlı değildir; sapma gösterirler. $\mathrm{Bu}$ sapmaların sonucu oluşan çarpmalarla dünyalar oluşur. İnsanlar, tıpk1 evrenlerdeki atomlar gibi, kendi başlarınadırlar ve hazzı-bireysel yararı ararlar. Dolayısıyla insan, doğrudan toplumsal-siyasal değildir. Ancak çarpmaların etkisiyle kendilerini toplumsal ortamda bulurlar. Sapma olayı, insanın özgür istencinin kaynağı olarak gösterilir. Böylece insan kendi yazgısını belirlemek konusunda aktiftir. Tıpkı atomlar gibi insan kendi kaderini nedensiz olarak kendi belirler. Bu bağlamda irade özgürlügünün ilk kez tam açıklıkla Epiküros’ta ifade bulduğu söylenebilir. İnsanlar, yaşanan kaos içinden sıyrılıp kendi hayatlarını, diğer bir deyişle kendi mutluluklarını yaratma gücüne sahiptir. Fizik, deneyimlerin geliştirilmesiyle ilgili olduğu için, eğitimle de yakından ilişkilidir. Ama bu eğitim de bir tür öz-eğitim olacaktır.

Marx'ın doktora tezini Demokritos ve Epiküros'taki atomlar düşüncesine yazmış olması, Epiküros’taki maddecilikle ilişkilidir; çünkü Epiküros'un materyalizmi, idealizmi reddeder; Marx’1 etkileyen yanı doğal felsefesinin bilimsel bilginin kuruluşu değil, öz-bilincin ataraksia'sına dayalı olmasıdır (Smith, 1999: 393). Bu Epiküros'un Aydınlanma düşünürlerinin, batıl inançlara ve dinsel kurumlara karşı, esin kaynağı olmasını sağlayacaktır (Eagleton, 2016:3). Bu materyalizm farklı açılardan Hobbes'u ve Locke'u da etkilemiştir. Locke'un mutluluk arayışı ve Hobbes'un korku'ya karşı bir egemen arayışı, somut dünyanın düzene sokulmasında insani hislerden yola çıkarak yeni bir düşünce kurma girişimleridir. Duygulanımları reddetmeden insan doğasını bilimin içine alan Epikürcü materyalizm, Kartezyen düalizmi reddetmiştir çünkü mekanik olmayan bir maddeciliğe dayanır (Smith, 1999:398).

Tanrılar ise dünyalar arası boşlukta yer alır. Tanrılar vardır ancak dünyevi şeylerle ilgilenmez, dolayısıyla ölüm korkusu kaçınılmazdır ama gereksizdir. Bu nedenle hem tanrılardan hem de ölümden korkmaya gerek yoktur. Ruh, bedenle birlikte yok olacaktır; dolayısıyla korku ve acılardan arınmak isteyen Epiküros'un bilge kişisi şu şekilde düşünür ve 
rahatlar: "Ölüm varken biz yokuz; o varken de biz yokuz”. Epiküros, Tanrıları toplumsal ve bireysel yaşantının dışına atarak, dünyevi bir düşünce kurma yönünde önemli bir adım atmıştır. Tanrıların gizemlerinden ve ölüm korkusundan sıyrılan düşünce sistemi, hazlara yönelebilmenin temelidir.

Epiküros'a göre sağlam bilginin ve doğrunun ölçüsü teorik olarak, duyu verileri ve bunların tekrarı ile zihnimizde edinilen izlenim; pratik olarak, haz ve acıdır. Dolayısıyla, Epiküros bir yandan deneycidir; temele insan yapıp etmelerini alır; öte yandan deneyimleri, insanın çektiği acıya ya da duyduğu hazza bağlar. Deneyimlerle elde edilecek zevkler, etken (arzulanan sonun elde edilmesi-açlığın giderilmesi gibi) ve edilgen (denge durumu-tokluk hali gibi) olmak üzere ikiye ayrılır. Epiküros için edilgen zevklerin daimiliği önemlidir çünkü onlar arzuyu uyarıcı bir acının varlığına dayanamaz ve acıdan uzak bir tür durgunluk halini simgeler. Epiküros için zevkin varlığından çok acının yokluğunu görmek daha önemlidir. Acısızlık tercih edilir. Haz, acıdan bağımsızlıktır. Korkudan sakınacak şekilde yaşamak gerekir. Temel olan doğal ve zorunlu ihtiyaçların/isteklerin giderilmesidir; zaten doğa, özü itibariyle, zorunlu olan ve kolayca elde edilebilir olanları ulaşılır kılmıştır.

Haz son amaçsa acı veren şeylerden uzak durulmalıdır; kamusal hayattaki şan, mutluluk verici olsa da tehlikeleri de çok fazladır ve yarışmacı hayatın içinde mutluluk kazanılmaz. "Bilinmeden yaşa”, Epiküros’un temel düşüncelerindendir (Rist, 1972:122; Schofield, 2000: 437). Yarışma dostluğu bozar, dostluğun bozulması da güvenlik kaybıdır. Fiziksel korunma için güvenlik önceliklidir. Epiküros'a göre mutluluk adına korunmak için dostluk kurarız; insan gerçekten mutlu olmadan bilge, asil ve adil olamaz (Rist, 1972:135). Bu düşüncelerin etkisi özellikle Hobbes’un güvenlik ve egemen devlet arayışında ve sözleşmeci düşünürlerin sivil toplum düşüncesinde kendini gösterecektir. Aşağıda değinilecek olan, siyasal düşünceleri de fiziksel güvenliğin temel olduğu toplulukçu bir çerçevede işleyecektir.

Dış etkenlere açıklık ve onlardan bağımsızlık Epiküros'ta birbiriyle bağlantılıdır. $\mathrm{Bu}$ aynı zamanda otoriteye bağlılık ama ona karşı esnek olmayı da içerir (Erler, 2011: 28-29). Diğer bir deyişle bireyin kendi alanını yaratma kapasitesi önemsenir. Kendi kendini eğitim/öz-eğitim (self-education) önemlidir. Bu çizgide onun takipçileri de onu geliştirecek alan bulmuştur. Epiküros verili maddi bütünden filozofun akıllıca seçimler yapabilme 
ihtiyacını geliştirir. Kendi doktrinine materyaller adapte ederken, tezat düşüncelerden de yararlanmıştır. Böylece gelenekle yenilenme arasında bir denge kurar. Seçici bir şekilde ödünç aldığ1 kavramlar, kendini yetiştirmeye dönüşür (Erler, 2011: 23-25). Bu onun deneyimci yanını, kişinin tercihlerini ve bu tercihleri kendi tarafından bir süreçten geçirilmesini önemli hale getirir.

Dolayısıyla hazza ulaşmada akla atfedilen rol, göz ardı edilmemelidir. Akı1 yoluyla doğru bilgiye ulaşmak esastır; ancak doğru bilgi ile acı ve haz arasındaki ayrım yapılabilir. Erdem ve bilgelik bize kendi kendine egemen olmayı sağlayacaktır, çünkü bize haz ve acı karşısında nasıl davranacağımızı, en çok haz ve en az acıyı nasıl elde edeceğimizi öğretir; erdem korku ve acıları yenmemizi öğretir. Erdem, Epikuros'a göre, kendinde bir amaç değildir; mutlu yaşam için bir araçtır. Bilgelik bizi tanrılar karşısındaki ölüm karşısındaki korkulardan kurtarır, ölçüsüz istekler karşısında özgür kılar; aynı zamanda bize acının gelip geçici olduğunu ve yenebileceğimiz bir şey olduğunu öğretir ve bize doğaya uygun bir yaşamanın yolunu gösterir. Doğaya uygun yaşam, bir tür arınmışlık ve kirlenmemişlik halidir. Diğer bir deyişle, durgunluk, ruhsal dinginlik, entelektüel duruluktur (ataraksia) ve bu durum, en büyük hazdır. Kendine yeterli olan doğru bir yaşam, insanı mutluluğa götürdüğü için en büyük zenginliktir. Bilge kişi, kimseye fark ettirmeden, düşman edinmeden yaşayan kişidir. Bilge sıradan insanların öylesine üstündedir ki, ölümlüler arasında bir tanrı gibi dolaşır. Alınyazısının da bilge üzerinde hiçbir etkisi olamaz, bilge bütün durumlarda mutludur. Bilge kişinin kanılarında sarsılmaz bir kesinlik ve bir değişmezlik vardır. Yalnızca bilge doğru olanı doğru bir biçimde yapmasını bilir (Ağaoğulları, 2006: 405-408). Bu bağlamda Epiküros’ta “insanı özgür olarak kendi kendine dayandırmak” yönünde bir çaba olduğu söylenebilir.

$\mathrm{Bu}$ çerçevede, O’Keefe'ye göre Epiküros’taki özgürlük, liberter bir özgürlüktür. Çünkü inançlarımız kontrolümüz altındadır. Kontrol bireydedir ancak bu zihinsel yaratılışın etkisindeki bir kontrol değil, geliştirilebilir bir alandır. İnançlarımız ve arzularımız, doğa hakkında doğru akıl yürütmenin sonucu olmalıdır. Hangi koşulların bizi mutlu edeceğine dair alternatif durumları müzakere etmek, aklımızı ihtiyaç ve arzularımı araştıracak şekilde kullanmak, hangi araçların mutlu hayata ulaşacağını düşünmek, rasyonel öz-yönetim sakinliğin kaynağı olabilir. Nasıl davranacağımız bize bağlıdır (O’Keefe, 2005:23-25). 
Eğitim (paideia) eleştirisi, bireyin ne olacağının belirlenmesi nedeniyle önemlidir. Antik dönemin geleneksel eğitimi (paideia olarak) kültürel formasyondur, kalabalıkların aşırı övgüsünü aldığı zaman özgür hisseden kişi yaratır. Doğa eğitimi, fizik, ise bağımsız ve kendiyle gurur duyan kişi yaratır, dışarıdan gelecek hareketlere karşı direnç yaratır. Foucault'ya da ilham veren bu eğitim eleştirisi, bireyi özgür bir özne haline getirir. Özgür özne (free subject), kendi'nin (self) ürünüdür. Özgür kişi (free man) ise kültürel retoriğin ürünüdür. Epiküros'un kapalı topluluğu ve eğitimi, kişisel dönüşüm ve kişisel uzmanlaşma sağlar (McGushin, 2007:117-118). Bu şekilde eğitimle kazanılan parrhesia (içten konuşma) ile bireyin otonomi arayışı, kendi'nin kollektif korunmasına dönüşür (Fletcher, 2012:70-71). Böylece kişinin kendi kurtuluşu ile diğerlerinin kurtuluşu arasında oluşan dostluk bağı topluluğu kurar.

\section{Güvenlik ve Dinginlik Arayışında Siyaset}

Epiküros, bir Helenistik dönem düşünürü olarak, topluluk içinde olumlanan bir yaşam tarzını ve insanın diğerleriyle birlikte ulaşacağı bir olgunluk durumunu yadsır; bunun tersine bireylerin teker teker mutluluklarının toplam mutluluğa eşit olacağına dönük bir bakış açısıyla siyaseti ve kamusal alanı ikincilleştirir. Çünkü O’na göre toplum doğal veya zorunlu değildir, dolayısıyla onun içinde bulunmak daha iyidir; mutluluk için toplumdan uzak durmak gerekir (Ağaoğulları, 2006: 406-408). Epiküros'a göre kamusal görevlerde bulunmak, insana acı verme potansiyeli taşır. Dolayısıyla bu tüp görevlerden ve siyasal hayattan uzak durmak gerekir. Varlık ve onur gibi arayışlar, memnun olunabilecek anlardan yani durgunluk durumlarından uzaklaştırır ve kişiyi huzursuz kılar.

$\mathrm{Bu}$ kaçış isteği onun siyaset-karşıtı gibi ele alınmasına neden olur. Esasen Epiküros apolitikliği önermez ama mental kargaşadan ve fiziksel acıdan uzak durmayı ister (Brown, 2009: 180). Dolayısıyla bireylerin yukarıda belirtildiği gibi hayatları üzerinde kontrolü olması adına, bu iki unsura dikkat ederek hareket etmeleri gerekir. Siyasetten beklentileri yükselmek, pozisyon kapmak ya da yükselme hırsı olmamalıdır. Dostluk, mutluluğa erişmek için gerekli olduğu gibi siyaset ancak acıdan uzak tutmak için var olmalıdır. Toplumsal yaşamın temeli güvenlik ve kendinden emin olmaktır; toplumda var oluş ve siyasetten uzak kalmak bunun için gereklidir (Schofield, 2000: 437). Bir arada yaşamak bir zorunluluk değildi, ancak 
faydalıdır. Adalet kendiliğinden var değildir, insan yaratımıdır, topluluktaki davranışlarımıza oluşturulur (O’Keefe, 2010). Bu bağlamda siyaset, insanın hayatını kolaylaştırdığı noktalarda, örneğin gereken yasaların çıkartılması açısından gereklidir, ancak ondan daha fazlası beklenemez. İşe yarar yasalar çıkarmak ve onlara uymak, insanı hazza götüreceği için tercih edilir. Helenistik dönemin kargaşasına uygun bir şekilde, sıkça değişen yönetimlerden ve siyasi krizlerden uzak kalmak isteyen Epikürosçu siyaset, dönemin fiziksel acılarından arınmak için otoriteyle mesafeli bir ilişki kurarken bunu değiştirmekle uğraşmamış ancak geleneksel doğrularını da kabul etmemiştir.

İnsanlar topluluk içinde diğer insanlara karşı haksızlık yapmaktan, getireceği sonuçlar nedeniyle kaçınırlar. Bulundukları durumdan daha kötü bir duruma geçecekleri için insanlar başkasına haksızlık yapmamalıdır. Dolayısıyla genel bir haksızlık ortamı yerine, kendinden taviz vererek, kendi haklarına saygı gösterilmesini sağlamak için, başkalarının haklarına saygı gösterirler. İnsanlar zevkin varlığından çok acının yokluğunu görmek istedikleri için, bir müdahalesizlik durumunu tercih ederler. Bu noktada yine yüzyıllar sonra negatif özgürlük olarak adlandırılacak bir çerçeveyi çizer Epiküros. Bir şeyden özgür olmak önceliklidir. Keza devlet de daha fazla haz için bir araçtır; insanları acıdan kaçmak için yaptı̆̆ı bir tür sözleşmedir. Bu sözleşmeyle acıdan kaçınırlar; yasalar da düzenin sürdürülmesi için gereklidir. Adalet acı duymama ve vermemek üzerine kurulu bir düzende gerçekleşeceğinden karşılıklı ilişkilerin bir işleyişe bağlanması gereklidir.

Epiküros bu tür bir toplumsallığı, “dostluk” kavramı ile tamamlar. Dostluk Epiküros için, sosyal bir idealdir. Topluluk içinde, korkularından kurtulup hazzı aramaya yönelmiş insanlar, birbirlerinin dostu olduğu-birbirlerine acı vermeyecekleri bir yapı kurarlar. Dostluğun temeli faydaya dayanır ve ancak faydaların ortaklığ dostluk değildir; bu dostluğun önşartıdır; faydalarını arayan insanlar bir araya gelecektir. Bu bir araya geliş ve doğru bilgiyle daha iyiye yönelme, Epikürosçuluğu Kiniklerin hazcılığından ayırır. Kiniklerin katıksız pasifizmine karşı, Epiküros'un akla dayalı bir "daha iyi hal" kurgusu vardır; dostluk üzerinden bir topluluk öngörür. Söz konusu öngörü, Helenistik dönemin kaosundan sıyrılmak için kayda değer bir işarettir. 
Dostluk, mutlu olmak adına istenir. Dostluk konusunda hazcı felsefesiyle çelişkili noktaları vardır. Mutlu olmak esassa dostlara farklı davranılabilir mi ya da arkadaşını kendin kadar sevebilir misin şeklindeki sorular Epiküros'un takipçileri tarafından farklı biçimlerde yorumlanmıştır. Ancak en nihayetinde Epiküros felsefesi hem bireyci hem de komünaldir. Mutluluk için başkalarının yardımına ihtiyaç vardır (O’Keefe, 2010). Bu nedenle Epiküros'un Bahçe'si, dışarıdakileri “yabancı, kendini burada daha iyi hissedeceksin!” diye çağırır. Epiküros için yabancı, korkularından kurtulmamış, dost olmayan, hazzı aramaya yönelmeyen kişidir. Onu akla dayalı bir metotla mutluluğa götüreceğini ve bilgisini mutlu olmak için yöneteceğini savunan Epiküros, dünyevi bir mutluluk anlayışının da temellerini atar. Yabancıların umut vaat eden bir hazcılık için, Kiniklerin değil Epikürosçuların kapısını çalması yerinde olacaktır.

Yaşadığ döneminin siyasi yapısı, onda ilerlemeye karşı bir şüphe uyandırdığı için, düşüncesini insan ve onun mutluluğu üzerinden kuran Epiküros, insanın korkularından arınmış bir şekilde yaşarsa, kendi özünü ve mutluluğunu yakalayabileceğini, bunun da ancak insanın kendisinin bilgisine ulaştığında gerçekleşeceğini vurgulamıştır. Bu yönde bir ütopya, dünyevi ve hümanist bir ufka doğru yürüyüşün temeli olacaktır. Dolayısıyla reddettiği siyaset, geleneksel ve o dönem için yerleşik olan türden olan siyasettir. Yeni bir insan ve özne kurma hedefi onu siyasal tartışmaların dışına atmaz; tersine yeni bir siyasal tartışma açmanın, köklü ve farklı bir eleştiriden türeyen siyasalın önünü açar.

\section{Sonuç}

Öfkenin, azgınlığın ve sayısallaştırılmış (böylece yaygınlaştırılmış) yalanların hakim olduğu post-truth döneminde dinginlik, haz ve toplulukçu bir dayanışma önerisi romantizm olarak algılanabilir. Roma'nın coşkun dönemlerinde otoriteyle mesafeli bir kimlik arayışı da benzer şekilde dışlanmıştı. Epiküros’un öğretilerinde klasik liberalizmin müdahalesizlik arayışındaki bireyi kadar materyalizmin somutluğu da yer alır. Maddi dünyanın kuruluşu, yeni bir bireyin ortaya çıkmasıyla ilgilidir ki burada iyi hissedilecek ve iyi yaşanacaktır. Fiziksel özgürlük, düzenin emrettiklerine karşı “yapmamayı tercih eden” Katip Bartleby’ı hatırlatır. Epikürosçu kaçış, var olan siyasetin değiştirilmesini imkansız gibi gösterse de sistemin işleyişini tıkadığı için yeni bir güzergah aramayı da zorunlu kılar. Bu zorunluluk, acı 
çekmeden, dingin ve kendi gibilerle kurulacak bir hatta inşa edilecektir. Epiküros'un atomcu fiziği, özneyi yeniden kuracak eğitimi, mutluluğu amaç edinen hazcı pratikleri, Doğa ile Akıl arasında denge kuran süreci antik dünyanın geleneklerini sorgulamış, ancak yeni kurulan düzene de olduğu gibi boyun eğmemiştir. $\mathrm{Bu}$ şekilde kitlelerin desteğini alarak belli pozisyonlara ne pahasına olursa olsun gelme iştahını siyaset olarak kodlayan halihazırdaki işleyişi/gerçekliği reddetmenin alternatif bir yolunu da bize sunar.

\section{Kaynakça}

Ağaoğulları, Mehmet Ali (2006) Kent Devletinden Imparatorluğa, Ankara: İmge Yayınları.

Brown, Eric (2009) "Politics and Society", The Cambridge Companion to Epicureanism, ed.: James Warren, Cambridge Press.

Davies, William (2016) “The Age of Post-Truth Politics”, https://www.nytimes.com/2016/08/24/opinion/campaign-stops/the-age-of-post-truthpolitics.html , 24.08.2016, Erişim: 10.04.2017.

De Witt, Norman W. (1954) Epicurus and His Philosophy, Minneapolis: University of Minnesota.

Dunt, Ian (2016), "Post-truth politics is driving us mad", http://www.politics.co.uk/blogs/2016/06/29/post-truth-politics-is-driving-us-mad , 29.06.2016, Erişim: 10.04.2017.

Eagleton, Terry (2016) Materialism, New Haven: Yale University Press.

en.oxforddictionaries.com (2016) "Word of the Year 2016 is...", https://en.oxforddictionaries.com/word-of-the-year/word-of-the-year-2016, Erişim: 09.04.2017.

Erler, Michael (2011) “Autoditact and Student: On the Relationship of Authority and Autonomy in Epicurus and Epicurean Tradition", Epicurus and the Epicurean Tradition, eds: Jeffrey Fish, Kirk R. Sanders, New York: Cambridge University Press. 
Fletcher, Richard (2012) “Epicurus's Mistresses: Pleasure, Authority and the Gender in the Reception of Kuriai Doxai in the Second Sophistic", Dynamic Reading: Studies in the Reception of Epicureanism, Eds.: Brooke Holmes, W. H. Shearin, Oxford University Press, s. 52-89.

Gigandet, Alain (2012) "Epicurean Presences in Foucault's the Hermeneutics of the Subject", Dynamic Reading: Studies in the Reception of Epicureanism, Eds.: Brooke Holmes, W. H. Shearin, Oxford University Press, s. 303-316.

Gökberk, Macit (1996) Felsefe Tarihi, İstanbul: Remzi Kitabevi.

Hammer, Dean (2014) Roman Political Thought: From Cicero to Augustine, Cambridge University Press.

McClelland, J. S. (1996) A History of Western Political Thought, London: Routledge.

McGushin, Edward F. (2007) Foucault's Askesis: An Introduction to the Philosophical Life, Northwestern University Press.

Nelson, Brian (2015) Western Political Thought: From Socrates to the Age of Ideology, Waveland Press.

O’Keefe, Tim (2005) Epicurus on Freedom, New York: Cambridge University Press.

O'Keefe, Tim (2010) Epicureanism, New York: Routledge.

Rist, J. M. (1972) Epicurus: An Introduction, Cambridge University Press.

Russell, Bertrand (1969) Batı Felsefesi Tarihi, İstanbul: Kitaş Yayınları.

Sabine ,George (1966) Siyasal Düşünceler Tarihi Cilt 1, Sevinç Matbaası.

Schofield, Malcolm (2000) "Epicureanism", The Cambridge History of Greek and Roman Political Thought, Eds.: Christopher Rowe, Malcolm Schofield, s. 437-439. 
Sharma, Urmila; Sharma, S.K. (2006) Western Political Thought, New Delhi: Atlantic Publisher.

Smith, G. W. (1999) "Sinful Science? Marx's Theory of Freedom from Thesis to Theses", Karl Marx's Social and Political Thought-Critical Assessments, Eds.: Bob Jessop, Russell Wheatley, s. 392-410.

Wilson, Catherine (2015) Epicureanism: A Very Short Introduction, Oxford Press. 